\title{
Grammatical consciousness-raising: a problem-solving, process-focused approach
}

\section{Wendy R. Kilfoil}

How can we address the teaching of English as a second language in South African secondary schools given what we know about the nature of language acquisition, learners' lack of exposure to mother tongue English speakers and their widely divergent language experience at primary school level?

This paper argues that grammatical consciousness-raising should be the basis of the secondary school syllabus. Current syllabuses do not adequately consider language acquisition processes. Although their aims are defined as 'communicative', syllabuses continue to focus on what language should be taught, with the result that they remain essentially lists of structures and functions.

Syllabuses should be completely redesigned to develop a coherent process-focused, problemsolving approach to second language teaching. At the moment there is a distinct reluctance to make any definitive pronouncements about the place of language instruction in the classroom. This has a detrimental effect on both teachers and leamers. The only way to cope with the developing language needs of the leamer in the secondary school is through a more conscious study of how language is used in natural discourse. $A$ more deliberate language control on the part of the learner will enhance the efficacy of extensive listening, speaking, reading and writing activities designed to supply input which is a necessary but not sufficient criterion for acquisition at this level.

Hoe kan ons die onderrig van Engels as 'n tweede taal in Suid-Afrikaanse sekondêre skole aanspreek, gegee ons kennis van die aard van taalverwerwing, die leerders se gebrek aan blootstelling aan Engels-moedertaalsprekers en hul uiteenlopende taalondervinding op laerskoolvlak?

Hierdie artikel voer aan dat grammatikale bewustheidsopskerping die basis van die sekondêre skoolleerplan behoort te wees. Huidige leerplanne neem nie taalverwerwingsprosesse voldoende in ag nie. Alhoewel hulle doelstellings as kommunikatief beskryf word, fokus leerplanne steeds op watter taalinhoude onderig moet word. Gevolglik bly leerplanne hoofsaaklik lyste van strukture en funksies.

Leerplanne behoort heeltemal herontwerp te word om 'n samehangende proses-gefokusde, probleemoplossingsbenadering tot tweede taalonderrig te ontwikkel. Tans is daar 'n duidelike onwilligheid om enige definitiewe uitspraak te lewer oor die plek van taalonderrig in die klaskamer. Dit het 'n nadelige uitwerking op onderwysers en ook die leerders. Die enigste manier waarop die ontwikkelende taalbehoeftes van die sekondêre skoolleerling geakkommodeer kan word, is deur 'n meer bewuste studie te maak van hoe taal in 'n natuurlike diskoers gebruik word. 'n Meer doelbewuste taalbeheer aan die kant van die leerder sal die doeltreffendheid van ekstensiewe luister-, praat-, lees- en skryfaktiwiteite bevorder. Hierdie aktiwiteite verskaf die nodige taalinsette, maar is op sigself onvoldoende om taalverwerwing op hierdie vlak te verseker. 
This Paper considers how to address English second-language teaching in the secondary school in South Africa, given the following factors:

* Firstly, while English is ostensibly a second language, in many areas it is, in fact, a foreign language, as learners have no exposure to English outside the classroom. This situation is further complicated in the case of Black education, where English is officially the medium of instruction. The abilities of both teachers and learners are often inadequate to cope with English as teaching-learning medium.

* Secondly, learners arrive in the secondary school having been exposed in the primary school to language teaching methods as diverse as grammar-translation, audio-lingualism and the communicative approach. Even learners who have been in a contact situation with first-language speakers and have acquired conversational skills, will not be able to implement this language experience and knowledge fully, because they have no conscious ability to interact with language.

Syllabuses reveal the compilers' concern with what to include in the curriculum in terms of formal language now that the teaching of grammar structures in a discrete and cumulative way has fallen into disfavour. Their attempt to synthethize a structural syllabus with communicative approach aims is an inadequate compromise and reveals an ambivalent attitude towards language teaching.

Grammatical consciousness-raising should be at the core of secondary school English syllabuses. One hesitates to make such an assertion, lest people interpret it to mean that a ready-made grammar should be imposed on learners and realized through the mechanical manipulation of linguistic structures. On the contrary, grammatical consciousness-raising aims at facilitating the natural acquisition process by making explicit what learners might already know implicitly, giving them more control and helping them to analyse language and then develop, tests and modify hypotheses about language use. In this editorial note to Rutherford's Second language grammar: learning and teaching, Candlin comments on grammatical consciousness-raising:

Its concern is with developing the learner's powers of judgement and discrimination in respect of the semantic and discoursal demands on the grammatical structures of the target language, emphasizing in this reflective mode how well the learner understands the relationships between form and meaning. In productive mode its concern is with enabling learners to adjust their grammar to reflect the location of their utterances in discourse, to extend their grammatical means for expounding particular logical and semantic relationships, and gradually to convert their prefabricated routines into analysed language (Rutherford, 1987: Preface).

The approach this paper is suggesting is process-focused, as it reflects the theory of firstlanguage acquisition posited by Chomsky in the late 1950s. Humans have an innate ability to acquire language. Any language is an organic and dynamic rule-based system or network of sub-systems which first-language learners will acquire in a particular order at their own pace, as long as they are exposed to meaningful language data or input. The process by which language is acquired is one of analysis and hypothesis formation (however unconscious). The learner is exposed to the language, detects a pattern, develops a hypothesis about how language works and tries it out. As a result, he might accept the rule, reject or modify it. The learner is continually modifying and refining his systematic language knowledge. His production of idiosyncratic constructions at any one stage of his linguistic development reflects his 'interlanguage'; that is, the extent of his mastery of the rules at that stage. Each learner's internal syllabus is individual; therefore, we should not impose a formal external syllabus on learners. Research cited by Ellis (1985) supports the idea that formal instruction has no effect on the route of the learner's acquisition; that is, he will not acquire a rule out of the normal sequence. Yet, second-language acquisition does not exactly parallel that of first language. There are 
factors other than input which affect acquisition; for example, age, motivation and attitudes. Exposure to language data is a necessary but not sufficient condition for acquisition, particularly when the classroom is the only source of data.

A problem-solving approach is advocated because it will involve learners - either individually or in pairs or groups - in a study of language data for the purpose of analysis and interaction. It is an inductive, holistic process, moving from discourse to structure.

Secondary school learners have been selected as the target group because at the adolescent stage they should be able to use cognitive strategies to reinforce their innate language acquisition ability and thus facilitate both the rate and success of their learning (Ellis: 1985). This is especially necessary when long stretches of discourse are involved because extralingual features such as organization begin to play a role. The conscious decisions involved in writing an expository essay, for example, are not part of natural language behaviour. Even first language speakers do not naturally understand or produce stretches of coherent discourse. Other cognitive strategies are thus required. Unfortunately, the only learning strategy which many.learners employ is memorization. Many have never explicitly been taught to analyse or make guesses or take risks. Grammatical conscious-raising develops these important strategies and makes language processes explicit. Furthermore, all learners arrive in the secondary school with some knowledge of language and, as Rutherford argues:

We might use C-R to bridge the gap between the learner's prior knowledge of how major constituents may be properly ordered for effective communication (the 'familiar') and the learner's ignorance of the special grammatical devices that English requires for the correct rendering of that order (the 'unfamiliar') (1987: 20-21).

Syllabus compilers, as mentioned earlier, have not developed a coherent approach to language teaching. A typical aim for an English second-language syllabus, currently in use, is to ensure 'communicative competence for personal, social, educational and occupational purposes' (Department of Education and Culture, Std 9 and 10, 1987: 2). This is hardly a standard interpretation of 'communicative'. The aim is elaborated in terms of developing the four skills and promoting 'pupils' control of English through a knowledge of its structure and usage (2). In the section of the syllabus entitled 'Language structure and usage' a list of structures is given, but the teacher is directed to the fact that a 'formal programme of work on language structures and usage is neither required nor appropriate' and that 'detailed attention should only be given to such items in class when a careful analysis of the class's performance has revealed the need for it' (7). Scattered throughout the sections on the four skills are lists of language functions.

A study of the syllabuses and the textbooks to which they have given rise, leads to certain inferences. Firstly, 'communicative' in its more generally understood sense of interpersonal communication is too narrow a concept to embody what the secondlanguage learner has to be able to do with English, even in the context of his schoolwork. Secondly, syllabus compilers are not quite sure what to do about grammar. There is, on the one hand, the erroneous assumption that a communicative approach excludes attention to form; that is, that exposure to language data or input is a sufficient as well as a necessary condition for acquisition. On the other hand, there is the obvious belief that, somehow, formal instruction can lead to acquisition, hence the lists of structures and functions included. The new textbooks reflect this general ambivalence. If both the syllabus compilers and the textbook writers vacillate on the grammar issue, how must the teacher feel?

The problem is that too many people equate language teaching with a discrete-point, deductive approach and, certainly, that is to be avoided. What we must do is teach language in a way that causes learners to interact with it in its semantic and discoursal context, so that they have more conscious control over it. In the writing section of the Std 9 and 10 syllabus which was discussed, teachers are required to guide pupils 'to plan, 
draft, revise and polish their work' (6). This process-approach to writing makes linguistic and discourse demands on learners for which they are ill-prepared by the type of language teaching they receive. Ask almost any teacher how to teach direct and indirect speech and he will tell you. Ask teachers how to realize the syllabus requirements for reading and the majority will be unable to describe how they would teach learners 'to respond to the features which show that a writer is introducing an idea, emphasizing a point, explaining or clarifying an idea, illustrating a point, changing a line of thought' (5) and so on.

If we want an approach which is practical and interactive and which will help learners to do what they have to do in English - that is, to process language - we shall have to redesign the syllabuses. Language study can be embodied in the syllabus in terms of the four skills as in some instances it already is. For example, to be able to recognize how a writer is doing certain things in a text, learners will have to analyse the language used. In other words, an important way to cope with learners' developing language needs in the secondary school is through a more conscious study of language. Syllabuses should not focus on what language should be learned but on how language works, and the criteria (grammatical, discoursal and semantic) for making certain choices in specific contexts rather than others. According to Rutherford,

C-R is the means to an end, not the end itself. That is, whatever is raised to consciousness is not to be looked upon as an artifact or object of study, to be committed to memory by the learner and thence recalled by him whenever sentences have to be produced. Rather, what is raised to consciousness is not the grammatical product but aspects of the grammatical process, and C-R activity must strive for consistency with this principle (1987: 104).

The question arises how such a language syllabus would be implemented in the classroom. The fact is that many activities already in use in the communicative approach are suitable for grammatical consciousness-raising. All we would need to do would be to use such activities consistently to give a process-focused, problem-solving syllabus the necessary coherence in presentation. The important point is that most activities involve working from the context of language data. Dunbar asserts:

By teaching language as isolated bits of knowledge, we deny what language really is. If, on the other hand, larger chunks of language are used and the bits examined phonologically, semantically, syntactically - they might make more sense to the learner. In other words, it may be more logical to go from the whole to examine the discrete points and see how they relate to the whole, rather than examine the discrete points in isolation and assume that they can later be reconstructed to some whole (Dunbar, 1988: 33).

Many teachers are already familiar with various activities which focus on cohesion, such as jigsaw reading (being able to reconstruct separate sentences into their original paragraph, using discourse markers and cohesive devices); using cloze as an exercise instead of a test; inserting a sentence into a text in the correct place or in a variety of ways focusing on cohesive devices in a text. Editing is another familiar activity. Dictogloss might not be as familiar. It involves the dictation of a passage from which learners note only key words. They then work in groups to reconstruct the passage (Wajnryb, 1988: 35). Rutherford suggests a 'propositional cluster' activity to make pupils aware of the obligatory subject in English. Pupils are given a verb and two nouns and have to decide on the subject. This choice influences the grammatical choices in the rest of the sentence. When the cluster is part of a larger context - that is, if it is preceded or followed by other sentences - the exercise illustrates how context determines grammatical choice. In order to focus on the relationship between words, especially when they link sentences, Rutherford suggests a three-sentence text with a grammatically ill-matched second sentence. The activity will be to rewrite the sentence. 
These are all separate activities and if they are used only occasionally in class, they will not contribute meaningfully to consciousness-raising. The starting point must be an appropriate syllabus and then the relevant activities can be co-ordinated.

What conclusions can thus be drawn about the place of grammatical consciousnessraising in the English second-language syllabus in the secondary school? Firstly, we have to consider the nature of the task (what we currently know about language acquisition) and secondly, the needs and goals of the learners (social, academic, and once they have left school).

It may be argued that explicit attention to form cannot effect acquisition. Possibly, it cannot alter the order of acquisition, but it could accelerate the process and ultimately make the learning more successful. It could also provide learners with a latent knowledge of language which could be activated later in communication situations. Certainly, when considering the needs of learners - for example to respond to literature, edit a text or write an expository essay - more conscious control of language is desirable.

Effective acquisition should be promoted in a variety of ways besides grammatical consciousness-raising of course, because language is multi-dimensional. Where learners have access to mother-tongue speakers, conversational interaction is invaluable. But many learners - even in urban areas - encouter English only at school. Another source of input is extensive reading, where the aim is enjoyment and attention to meaning. Unfortunately, some learners have limited access to library facilities. A third way is to increase the learners' written output in such a way that meaning, not form, is paramount; for example, using journal dialogues. However, where the classroom remains the main resource for language data, grammatical consciousness-raising should be the focus of the English second-language syllabus. Therefore I reiterate that syllabuses should be redesigned. They should be based on problem-solving and focus on how language is acquired. This does not mean that the focus should again shift to form as opposed to meaning. Grammatical consciousness-raising is pre-eminently a facilitating strategy to enable or empower learners to extract or express meaning effectively.

\section{REFERENCES}

ALLEN, J.P.B. and S.P. Corder. 1980. Reading for applied linguistics. Oxford: Oxford University Press.

BOURKE, J.M. 1989. The grammar gap. Forum. XXVII:3:20-4.

CELCE-MURCIA, M. and L. McIntosh (Eds.) 1989. Teaching English as a second or foreign language. U.S.A.: Newbury House.

CHAMPEAU DE LOPEZ, C.L., 1989. The role of the teacher in today's language classroom. Forum. XXVII:3:2-6.

DUNBAR, S. 1988. From the whole discretely. Forum. XXVI:3:32-4.

ELLIS, R. 1985. Understanding second language acquisition. Oxford: Oxford University Press.

JOHNSTONE, R. 1989. Communicative interaction: a guide for language teachers. London: Centre for information on language teaching and research.

KAPLAN, R.B. 1985. Applied linguistics, the state of the art: Is there one? Forum. XXIII:2:2-7.

KRASHEN, S.D. 1982. Principles and practice in second language acquisition. Oxford: Pergamon.

LARSEN-FREEMAN, D. 1987. From unity to diversity: twenty-five years of languageteaching methodology. Forum. XXV:4:2-11. 
LENNON, P. 1988. The linguist and the language teacher: love at first sight or the end of the honeymoon? Forum. XXVI:4:2-6.

RUTHERFORD, W.E. 1987. Second language grammar: learning and teaching. London: Longman.

WAJNRYB, R. 1988. The dictogloss method of language teaching: a text-based, communicative approach to grammar. Forum. XXVI:3:35-9.

WIDDOWSON, H.G. 1978. Teaching language as communication. Oxford: Oxford University Press.

WIDDOWSON, H.G. 1984. Learning purposes and language use. Oxford: Oxford University Press.

WIDDOWSON, H.G. 1984. Explorations in applied linguistics. Oxford: Oxford Unversity Press.

WINITZ, H. (Ed.) 1981. The comprehension approach to foreign language instruction. Rowley: Newbury House. 